Full length article

\title{
Spanish validation of the Internet Gaming Disorder-20 (IGD-20) Test
}

\author{
Héctor Fuster ${ }^{\text {a, }}$, Xavier Carbonell ${ }^{\text {a }}$, Halley M. Pontes ${ }^{\text {b }}$, Mark D. Griffiths ${ }^{\text {b }}$ \\ a Ramon Llull University, FPCEE Blanquerna, Císter 34, 08022 Barcelona, Spain \\ ${ }^{\mathrm{b}}$ International Gaming Research Unit, Nottingham Trent University, Burton Street, Nottingham, NG1 4BU, UK
}

\section{A R T I C L E I N F O}

\section{Article history:}

Received 8 July 2015

Received in revised form 23 November 2015

Accepted 26 November 2015

Available online $\mathrm{xxx}$

\section{Keywords:}

Gaming addiction

Internet gaming disorder

Video games

IGD-20 test

Behavioural addictions

\begin{abstract}
A B S T R A C T
In recent years, problematic and addictive gaming has been a phenomenon of growing concern worldwide. In light of the increasing awareness about this issue, the latest (fifth) edition of the American Psychiatric Association's Diagnostic and Statistical Manual of Mental Disorders (DSM-5) included Internet Gaming Disorder (IGD) as an area in need of more empirical research. The Internet Gaming Disorder Test (IGD-20 Test) was developed as a valid and reliable tool to assess IGD. The aim of the present study was to validate the Spanish version of the IGD-20 Test, and analyze the different profiles found among a sample of 1074 Spanish-speaking gamers. A confirmatory factor analysis showed the validity of the Spanish version of the IGD-20 Test and its six factor structure (i.e., salience, mood modification, tolerance, withdrawal, conflict and relapse). The latent profile analysis (LPA) showed five different gamer classes. The 'disordered gamers' class comprised $2.6 \%$ of the participants. Based on this class, sensitivity and specificity analyses showed an adequate empirical cut-off point of 75 (out of 100). It is concluded that the Spanish version of the IGD-20 Test is valid and reliable and can be used in research into IGD among Spanish speaking populations.
\end{abstract}

๑) 2015 Elsevier Ltd. All rights reserved.

\section{Introduction}

\subsection{Internet gaming disorder}

Ever since Griffiths (1995) coined the term 'technological addictions', research in this field has grown considerably, especially in the area of addiction to videogames and Massively Multiplayer Online Role-Playing Games (MMORPGs) (Carbonell, Guardiola, Beranuy, \& Bellés, 2009). In light of increasing awareness and empirical research into this issue in North America, Europe and Asia, the American Psychiatric Association [APA] (American Psychiatric Association, 2013) included Internet Gaming Disorder (IGD) as an area in need of further research in its recent fifth edition of the Diagnostic and Statistical Manual of Mental Disorders (DSM-5). According to the DSM-5, there are nine criteria that comprise a diagnosis of IGD: (i) preoccupation with internet games; (ii) withdrawal symptoms when internet games are taken away; (iii) tolerance, resulting in an increase in the amount of time spent playing internet games; (iv) unsuccessful attempts to control participation in internet games; $(v)$ loss of interest in previous

\footnotetext{
* Corresponding author.

E-mail address: hectorfl@blanquerna.url.edu (H. Fuster).
}

hobbies as a result of, and with the exception of, internet games; (vi) continued excessive use of internet games despite knowledge of the resulting psychosocial problems; (vii) deceiving family members, therapists and others with regard to the amount of internet gaming; (viii) use of internet games to escape from or reduce negative moods; and (ix) jeopardizing or losing a significant relationship, job or educational opportunity due to online gaming (APA, 2013). An individual who endorses five or more of these criteria over a period of 12 months is considered to be a disordered gamer.

Griffiths (2005) has argued that while there are always some idiosyncratic differences between addictive behaviors, there are six common components that comprise both chemical and behavioral addictions (i.e., salience, mood modification, tolerance, withdrawal symptoms, conflict and relapse). As has been noted previously (Griffiths, King, \& Demetrovics, 2014), the nine IGD criteria correspond to the six components proposed in Griffiths' addiction model (2005). Support for the model comes from a number of studies that have developed and validated behavioral addiction scales and instruments using the six components for behaviors such as exercise addiction (Terry, Szabo, \& Griffiths, 2004), shopping (Andreassen et al., 2015), gaming addiction (Lemmens, Valkenburg, \& Peter, 2009), work addiction (Andreassen, Griffiths, Hetland, \& Pallesen, 2012a), internet addiction (Kuss, Shorter, van Rooij, Griffiths, \& 
Schoenmakers, 2014), and social networking addiction (Andreassen, Torsheim, Brunborg, \& Pallesen, 2012b).

Based upon this model, Pontes, Király, Demetrovics, and Griffiths (2014) developed the Internet Gaming Disorder Test (IGD-20 Test), a 20-item scale designed to assess IGD. Psychometric analyses of the IGD-20 Test displayed good results in terms of both validity and reliability. In addition, the results obtained from the model showed an acceptable degree of fit with confirmatory factor analysis (CFA), lending support to the test's factorial validity. More specifically, the test's criterion validity and concurrent validity were justified via the significant correlations existing between IGD-20 test results and (i) hours of weekly game play and (ii) the nine criteria for IGD in the DSM-5.

\subsection{Assessment of problematic gaming}

The assessment of problematic gaming has received extensive scholarly attention and has been subject to numerous debates due to the current unofficial status of this condition and the more general negative methodological effects and possible biases resulting from methodological and conceptual inconsistencies in the field (see Griffiths, Kuss, \& King, 2012; Griffiths, Király, Pontes, \& Demetrovics, 2015; Lopez-Fernandez, 2015). Additionally, there are a growing number of researchers in the field that have suggested that the new IGD criteria should be psychometrically tested from several perspectives including cross-culturally (Griffiths et al., 2014, 2015; Petry \& O'Brien, 2013). Moreover, Petry et al. (2014) recommended that: "establishing the psychometric properties of instruments assessing these nine criteria should begin using a crosscultural perspective" (p. 6).

In line with these guidelines, the present authors share the views of Petry, Rehbein, Ko, and O'Brien (2015) in which "more research is needed using assessment tools with established psychometric properties to address potential cross-cultural, as well as racial and ethnic, differences in IGD" (p. 3). Therefore, the development of the IGD-20 Test may be beneficial and help advance the field in several ways. Firstly, defining problematic gaming using a more standard and officially recognized framework (i.e., IGD) is likely to help mitigate future confusion as to what the problem behavior is in terms of conceptualization, which in turn may help standardize its nomenclature. This is a commonly identified caveat in the field as suggested by Pontes and Griffiths (2014). Secondly, as pointed out by several authors (e.g., Griffiths et al., 2014; Pontes \& Griffiths, 2014), if problematic gaming is to be fully recognized by official medical bodies as a behavioral addiction in the future, researchers should adopt a unified and commonly agreed approach at the assessment level because only then, standardization and reliable cross-cultural comparisons without the widely known methodological biases such non-unified approach accompanies will be possible (see Griffiths et al., 2014; Petry \& O'Brien, 2013; Pontes \& Griffiths, 2014). Therefore, it can be argued that the development and psychometric validation of a problematic gaming instrument that attempts to unify the field in terms of labeling (i.e., nomenclature) and assessment, may represent a step forward towards this ultimate goal.

Notwithstanding these issues, problematic gaming has also been an area of increasing research in Spain over the last decade (e.g., Fuster et al., 2012; Fuster, Chamarro, Carbonell, \& Vallerand, 2014) as evidenced by the many different screening instruments in the Spanish language. In fact, to date, there have been six Spanish-language instruments developed to assess the problematic use of videogames (see Table 1 ).

Although this particular area of research has been steadily growing in Spain, an instrument to assess problematic gaming that is based on a more updated framework such as the DSM-5 IGD criteria that is apt for use with any genre of videogames (i.e., online or offline) is unfortunately lacking. Therefore, the aim of the present study was to translate and validate a Spanish version of the IGD-20 Test developed by Pontes et al. (2014), and to identify and characterize different player profiles based on their gaming behavior as measured by the IGD-20 Test. By conducting this study, the authors envisage that the translated and validated instrument will facilitate unified research of problematic gaming in the Spanish cultural context by means of providing an updated standardized tool to assess IGD.

\section{Materials and method}

\subsection{Participants}

The sample comprised 1074 individuals all of who were gamers, aged between 12 and 58 years $(M=26.14$ years; $S D=6.1$ years $)$. Of these, $94.6 \%$ were male $(n=1016)$.

\subsection{Measures}

\subsubsection{Socio-demographic data}

The study collected information on the participants' gender, age, country of residence, age the participant began gaming, and relationship status.

\subsubsection{Data on gaming}

Information was collected on the number of hours played per week, the platforms used to play (e.g., personal computers, games consoles, etc.) and their favorite kinds or game genres (e.g., action, graphic adventure and puzzle, among others). MOBA (Multiplayer Online Battle Arena) games and MMORPGs were considered here to be relevant categories in and of themselves due to both public and academic concern as to their addictive potential, even though they are generally viewed as subgenres of strategy and role-playing games, respectively.

\subsubsection{Spanish IGD-20 Test}

The IGD-20 Test (Pontes et al., 2014) comprises 20 items that are answered using a five-point Likert-type scale: 1 ("Strongly disagree"), 2 ("Disagree"), 3 ("Neither agree nor disagree"), 4 ("Agree") and 5 ("Strongly agree"). These 20 items assess both online and offline video gaming activity engaged in over the previous 12 months in terms of the diagnostic criteria for IGD (American Psychiatric Association, 2013). At the same time, the 20 items are mapped onto the theoretical addiction components model set out by Griffiths (2005) due to the overlaps between the nine IGD criteria and the components model of addiction. Consequently, the IGD-20 Test assesses six different dimensions: salience, mood modification, tolerance, withdrawal symptoms, conflict and relapse.

\subsection{Procedure}

Sampling was conducted in March and April 2015. Participants were invited to take part in the study via a link that was featured on five online gaming forums. An online method was employed due to its many advantages including easy access to a wide-ranging sample of participants, in this case, gamers (Griffiths, 2010, 2012). The questionnaire was created using the open-source software LimeSurvey (version 2.05). The questionnaire was stored online and 
Table 1

Spanish-language instruments developed to assess the problematic use of videogames.

\begin{tabular}{|c|c|c|c|c|c|}
\hline $\begin{array}{l}\text { Author and year of } \\
\text { publication }\end{array}$ & Name of scale & Sample of validation & $\begin{array}{l}\text { Number } \\
\text { of items }\end{array}$ & Number of factors & $\begin{array}{l}\alpha \\
\text { Cronbach }\end{array}$ \\
\hline $\begin{array}{l}\text { Tejeiro and Bersabé } \\
\text { (2002) }\end{array}$ & $\begin{array}{l}\text { Problem Video Game } \\
\text { Playing Questionnaire } \\
\text { (PVP) }\end{array}$ & $\begin{array}{l}223 \text { students aged between } 13 \text { and } 18 \\
\text { years }\end{array}$ & 9 & Unidimensional & .69 \\
\hline Pedrero et al. (2007) & Not specified & $\begin{array}{l}\text { Two samples: } 413 \text { patients of an urban } \\
\text { Health Centre, and } 117 \text { of an Attention } \\
\text { Centre for Drug Dependencies }\end{array}$ & 4 & Not specified & .70 \\
\hline $\begin{array}{l}\text { Chóliz and Marco } \\
\text { (2011) }\end{array}$ & $\begin{array}{l}\text { Video Game Dependence } \\
\text { Test (VDT) }\end{array}$ & $\begin{array}{l}327 \text { boys and } 294 \text { girls aged between } \\
10 \text { and } 16 \text { years }\end{array}$ & 32 & $\begin{array}{l}\text { Four factors: withdrawal, overuse and tolerance, } \\
\text { problems, lack of control }\end{array}$ & .94 \\
\hline $\begin{array}{l}\text { Labrador, Villadangos, } \\
\text { Crespo, and Becoña } \\
(2013)^{*}\end{array}$ & Not specified & $\begin{array}{l}2747 \text { students in secondary and higher } \\
\text { education }\end{array}$ & 26 & $\begin{array}{l}\text { Seven factors: one for each technology (Internet, video } \\
\text { games, mobile, television), plus three others, which } \\
\text { grouped similar behavior in the various technologies }\end{array}$ & .87 \\
\hline $\begin{array}{l}\text { Lopez-Fernandez, } \\
\text { Freixa-Blanxart, and } \\
\text { Honrubia-Serrano } \\
\text { (2013) }\end{array}$ & $\begin{array}{l}\text { Problematic Internet } \\
\text { Entertainment Use Scale } \\
\text { for Adolescents (PIEUSA) }\end{array}$ & $\begin{array}{l}1131 \text { high school students aged } \\
\text { between } 12 \text { and } 18 \text { years }\end{array}$ & 20 & Unidimensional & .92 \\
\hline Chamarro et al. (2014) & $\begin{array}{l}\text { Cuestionario de } \\
\text { Experiencias } \\
\text { Relacionadas con los } \\
\text { Videojuegos (CERV) }\end{array}$ & $\begin{array}{l}7168 \text { students aged between } 12 \text { and } 18 \\
\text { years }\end{array}$ & 17 & $\begin{array}{l}\text { Two factor model: psychological dependence and use for } \\
\text { evasion, negative consequences of using video games }\end{array}$ & .86 \\
\hline
\end{tabular}

* This instrument assesses the problematic use of television, the internet, mobile phones and videogames.

was set up to ensure that the data collected were anonymous. A total of 1593 gamers began the survey but 475 survey responses were eliminated as incomplete. A record of the Internet Protocol (IP) addresses of participants was kept in order to avoid multiple responses, resulting in a further 20 responses being eliminated. In addition, the starting and ending times of the completion of the questionnaire were recorded, and responses of the 15 participants who completed the survey in less than 3 min were also eliminated from consideration to ensure that participants had taken enough time to read and understand the content of the questionnaire. Finally, nine other responses were eliminated as they were deemed to be logically inconsistent (for example, those reporting playing zero hours a week or being only two years of age). After checking for outliers, the final sample comprised 1074 participants.

The original English version of the IGD-20 Test was translated into Spanish using a step-by-step process as described by Sperber (2004). Briefly, these steps include: (i) translation into Spanish by two native English speakers with Spanish fluency; (ii) the comparison of the two translations and the drafting of a provisional translation; (iii) back translation into English by another independent translator; and (iv) comparison of the original translation and the back translation and reconciliation of any problematic items. The resulting Spanish version of the IGD-20 Test was subjected to a pilot study with a sample of 30 student gamers. There were no apparent problems in the perception and understanding of the content of the survey.

\subsection{Data analysis}

A Mahalanobis Distance analysis was conducted in order to identify multivariate outliers within the sample, making use of a threshold value of $p<.001$ (Tabachnick \& Fidell, 2007). The Shapiro-Wilk (S-W) univariate normality tests suggested that there could be a reasonable assumption of normality for the variables involved in the analysis. In order to validate the Spanish-language version of the IGD-20 Test, a CFA was conducted, using maximum likelihood estimation with robust standard error (MLR) in MPLUS 6.12 (Muthén \& Muthén, 2011). The evaluated indicators of fit include Chi-square $p$ value of greater than .05 , the Comparative Fit Index (CFI), the Tucker Lewis fit index (TLI), and the Root Mean Square Error of Approximation (RMSEA). One can infer that there is a good fit when CFI and TLI are greater than .90 and RMSEA is less than .06 (Hu \& Bentler, 1999).

In order to confirm that the classes identified by Pontes et al. (2014) were consistent and identified disordered users of videogames, a latent profile analysis (LPA) was conducted using MPLUS 6.12. When using LPA, a series of statistical and theoretical considerations are taken into account in order to obtain a model that best fits the data and identifies groups of people with similar responses for certain variables. LPA is a mixture-modeling and statistical clustering technique and the processes involved are data-driven (Lanza, Flaherty, \& Collins, 2003). LPA uses all observations of the continuous dependent variable (i.e., the scores in the IGD-20 Test) to define these classes via maximum likelihood estimation (Little \& Rubin, 1987). The probability that an individual is properly classified - which enables each person to be categorized into the best-fitting class - is estimated simultaneously with the overall model (Hill, Degnan, Calkins, \& Keane, 2006). The analysis was conducted while taking into account the Akaike Information Criterion (AIC) and the Bayesian Information Criterion (BIC) as well as the Sample Size Adjusted BIC (SSABIC). In addition, the adjusted likelihood-ratio test (LoMendell-Rubin Adjusted LRT Test) was used to assess the degree of fit between two nested models that differ in a given class. The statistics of relative entropy was also used as an indicator of the goodness of the classification of the individuals according to the model (values approaching 1 signify a high certainty in classification). Models where estimated with classes added iteratively to determine which model had the best fit to the data. When considering which model fitted the data best, the model with the lowest AIC, BIC and SSABIC was considered. The LMR Test and relative entropy value were used to select the best model of two or more models that shared similar information criteria (i.e., AIC, BIC and SSABIC). The categorical latent variables obtained are empirical variables that represent classes of individuals who share similar IGD-20 Test results.

Finally, a ROC (receiving operating characteristic) curve analysis was conducted, with the class entitled "disordered gamers" used as the gold standard in order to assess the instrument's capacity to distinguish between two elements in a binary classification (i.e., 'disordered gamers' and 'non-disordered gamers'). The ROC curve analysis allowed for the identification of cutoff 
points based on its sensitivity (i.e., the percentage of true positives among disordered gamers) and its specificity (i.e., the percentage of true negatives among non-disordered gamers). In addition, the probability of the IGD-20 Test producing a correct diagnosis through positive and negative predictive values was examined (PPV and NPV).

\section{Results}

\subsection{Descriptive statistics}

The mean average age participants began playing videogames was 7.75 years $(S D=3.29$ years), and they played a mean average of 19.46 h per week, with $21.13 \%$ playing 30 or more hours per week $(n=227)$. The participants played on average on three different gaming platforms, with $21.79 \%$ playing on five different platforms or more $(n=234)$. All the descriptive statistics are shown in Table 2.

\subsection{Validation of the IGD-20 Test}

The CFA of the six-factor model (i.e., salience, mood modification, tolerance, withdrawal symptoms, conflict and relapse) showed the model had an acceptable degree of fit for the IGD-20 Test: $\chi 2(155, n=1074)=769.07, p<.0001 ; C F I=.93 ; T L I=.92$ RMSEA $=.05$ (90\% CI: .053-.062). A relationship was observed between the total score for the IGD-20 Test and its factors, and both the hours of game play and the age of the player. As shown in Fig. 1, the factorial weights of all the items were greater than .50 for each respective factor, with the exception of items 2 and 19. There were correlations between all the factors, with values ranging from .61 to .95. In addition, the various factors displayed acceptable internal consistencies, with values for Cronbach's alpha coefficients ranging between .61 and .85 (see Table 3). Accordingly, Cronbach's alpha for all 20 items of the IDG-20 Test was .87 , which is very high. In sum,

Table 2

Descriptive statistics of participants, relationship status, platforms and game genres.

\begin{tabular}{lrr}
\hline & $n$ & $\%$ \\
\hline Gender of the participants & & \\
Male & 1016 & $94.6 \%$ \\
Female & 58 & $5.4 \%$ \\
Relationship status & & \\
Single & 643 & $59.9 \%$ \\
Stable partner & 353 & $32.9 \%$ \\
Married & 74 & $6.9 \%$ \\
Separated & 4 & $.4 \%$ \\
Game platforms & & \\
Personal computer & 934 & $87.4 \%$ \\
Mobile device & 613 & $57.1 \%$ \\
7th generation console (PS3, Xbox 360 and Wii) & 683 & $63.6 \%$ \\
8th generation console (PS4, Xbox ONE and Wii U) & 387 & $36.0 \%$ \\
Portable console (PSP and Nintendo DS) & 498 & $46.4 \%$ \\
Favorite videogame genres & & \\
Action (FPS, TPS, Shmups, etc.) & 584 & $54.4 \%$ \\
Strategy (RTS, TBS, 4x, etc.) & 185 & $17.2 \%$ \\
Role-playing (cRPG, JRPG, ARPG, etc.) & 609 & $56.7 \%$ \\
Adventure (Graphic adventure, Visual novel, etc.) & 218 & $20.3 \%$ \\
Puzzle & 53 & $4.9 \%$ \\
Sports & 129 & $12.0 \%$ \\
MOBA & 194 & $18.1 \%$ \\
MMORPG & 130 & $12.1 \%$ \\
\hline No. & & \\
\hline & &
\end{tabular}

Note. FPS $=$ First Person Shooter. TPS $=$ Third Person Shooter. RTS = Real Time Strategy. TBS $=$ Turn-Based Strategy. $4 \mathrm{x}=$ Explore Expand Exploit Exterminate. $\mathrm{cRPG}=$ Computer Role Playing Game. JRPG = Japanese Role Playing Game. ARPG = Action Role Playing Game. MOBA = Multiplayer Online Battle Arena. $\mathrm{MMO}=$ Massively Multiplayer Online Games. the results from the CFA support the factorial validity of the Spanish IGD-20 Test while the correlations found lend further evidence to the instrument's criterion-related validity as the overall IGD-20 scores were associated with relevant criterion variables in the expected direction.

\subsection{Latent profile analysis (LPA)}

When the LPA was carried out for the six dimensions of the IGD20 Test, a five-class solution emerged as the optimal solution (see Table 4). As shown in Table 3, the values for the AIC, BIC, and SSABIC all decreased steadily and at a consistent rate as more classes were added to the model. The addition of the fifth class brought about a leveling off of the decrease on all goodness of fit indices, suggesting that it was not necessary to add any more classes. Finally, a further inspection of the LMR test results clearly indicated that the fiveclass solution should be chosen in favor of all other classes even though the entropy levels of the two-class solution reached the best value.

The first of the five classes comprised "casual gamers" $(n=359$; $33.4 \%$ ), who scored below average on the scale, and the second comprised of "regular gamers", whose scores were about average ( $n=489 ; 45.5 \%$ ). The third of the classes comprised "engaged gamers at low risk" ( $n=128 ; 11.9 \%)$, while the fourth comprised "engaged gamers at high risk" ( $n=70 ; 6.5 \%)$. The main distinction between these two classes was that the latter scored significantly higher on the conflict and relapse dimensions of the IGD-20 Test. Finally, the fifth class comprised "disordered gamers" $(n=28 ; 2.6 \%)$. Those who belonged to this class scored consistently higher on all six dimensions of the IGD-20 Test (see Fig. 2). It should also be noted that participants with membership to this class essentially comprised younger gamers that played more hours than the rest of the gamers (see Table 5).

A Wald equality of means test revealed the association between the different classes and the genres or types of games preferred by each of them $\left(\chi^{2}=91.52, p<.001\right)$ (see Fig. 3 ). In addition, a pairwise comparison was carried out of the equality of means of age, hours of play, and IGD-20 Test score for each videogame genre (see Table 6). The results of this analysis further suggested that gamers who played MOBA and MMORPGs games were those who spent the most time playing and who scored the highest on the IGD-20 Test.

\subsection{Cut-off point}

The result of the ROC curve analysis showed an area under the curve (AUC) of .99 and the overall ability of the IGD-20 Test to discriminate between disordered and non-disordered gamers is excellent (see Fig. 4). Table 7 shows the sensitivity, specificity, positive predictive value (PPV), negative predictive value (NPV) and accuracy (ACC) of the IGD-20 Test and its various cutoff points, calculated using the "disordered gamers" class as the gold standard (i.e., classifier). The analysis resulted in a cutoff point of 75 to distinguish "disordered gamers" from non-disordered gamers. This cutoff point obtained a specificity of $99 \%$ and a sensitivity of $71 \%$. Thus, there were almost no cases of false positives and a significantly low amount of false negatives (i.e., gamers belonging to the class of engaged gamers at high risk). It should also be pointed out that the PPV and the NPV were 91\% and 99\%, respectively, which means that just $9 \%$ of the gamers who tested negative and $1 \%$ of those who tested positive were misdiagnosed. Finally, the ACC was $99 \%$. 


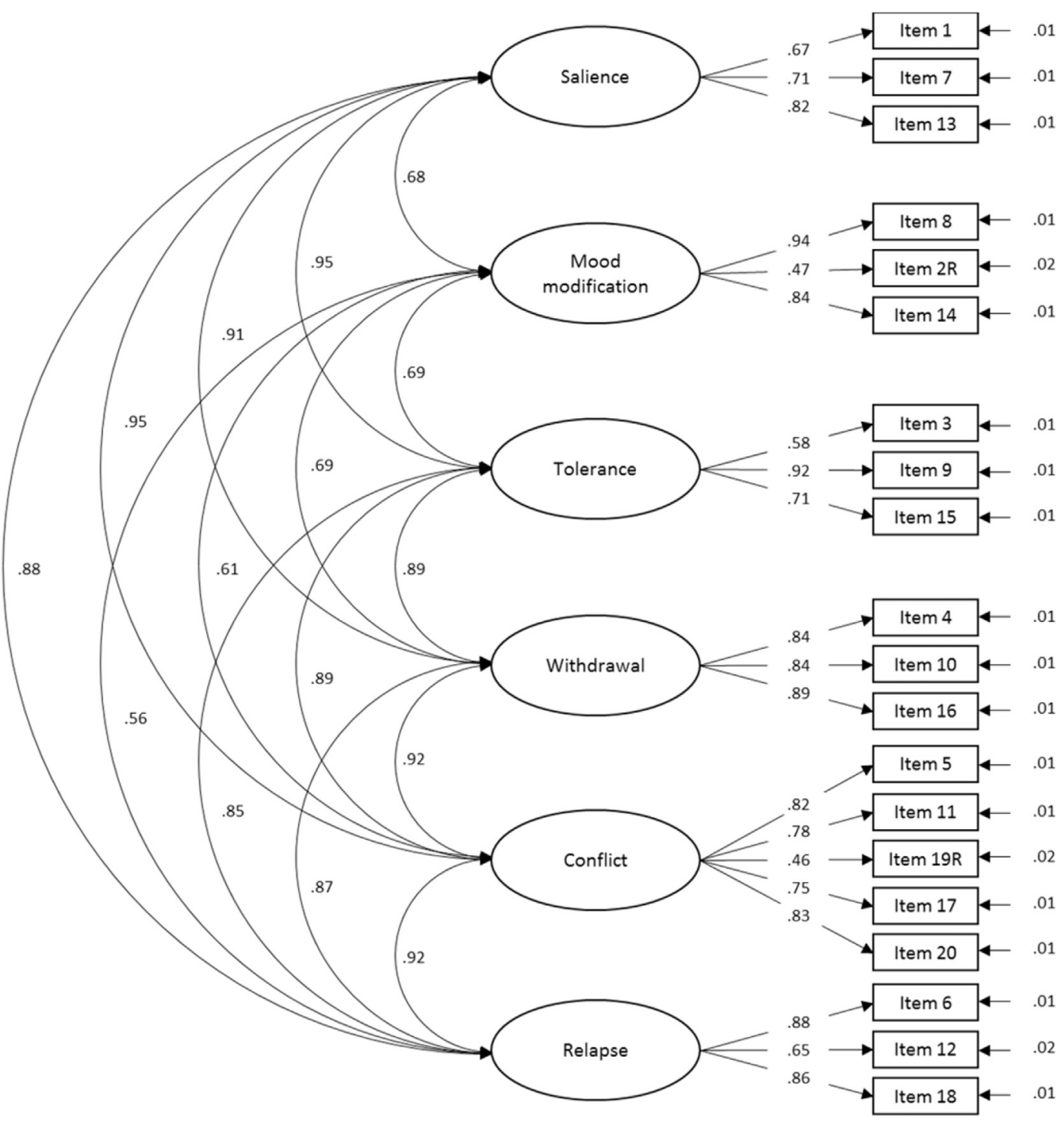

Fig. 1. Confirmatory factor analysis diagram.

Table 3

Correlations and descriptive statistics of the factors in the IGD-20 Test.

\begin{tabular}{|c|c|c|c|c|c|c|c|c|c|}
\hline & 1 & 2 & 3 & 4 & 5 & 6 & 7 & 8 & 9 \\
\hline 1. Salience & 1 & - & - & - & - & - & - & - & - \\
\hline 2. Mood modification & .68 & 1 & - & - & - & - & - & - & - \\
\hline 3. Tolerance & .95 & .69 & 1 & - & - & - & - & - & - \\
\hline 4. Withdrawal & .91 & .69 & .89 & 1 & - & - & - & - & - \\
\hline 5. Conflict & .95 & .61 & .89 & .92 & 1 & - & - & - & - \\
\hline 6. Relapse & .88 & .56 & .85 & .87 & .92 & 1 & - & - & - \\
\hline 7. IGD-20 & .80 & .63 & .73 & .76 & .82 & .74 & 1 & - & - \\
\hline 8. Hours & .51 & .20 & .30 & .26 & .31 & .27 & .42 & 1 & - \\
\hline 9. Age & -.15 & -.12 & -.14 & -.10 & -.10 & -.11 & -.12 & -.13 & 1 \\
\hline Mean & 7.70 & 8.00 & 5.93 & 5.42 & 10.49 & 6.55 & 44.08 & 19.46 & 26.14 \\
\hline$S D$ & 2.91 & 3.11 & 2.50 & 2.53 & 3.94 & 2.61 & 13.19 & 16.13 & 6.10 \\
\hline$\alpha$ & .68 & .79 & .61 & .85 & .76 & .66 & & & \\
\hline Standardized factor determinacies & .92 & .92 & .92 & .91 & .93 & .90 & & & \\
\hline
\end{tabular}

Note. All correlations were significant at the $\mathrm{p}<.01$ level. 
Table 4

Results of the latent class analysis.

\begin{tabular}{llllll}
\hline Number of classes & AIC & BIC & SSABIC & LMR test & Entropy \\
\hline 2 classes & 15066.48 & 15161.08 & 15100.74 & $\mathrm{p}<.01$ & .83 \\
3 classes & 14527.43 & 14656.89 & 14574.31 & $\mathrm{p}<.01$ & .80 \\
4 classes & 14355.10 & 14519.41 & 14414.59 & $\mathrm{p}<.05$ & .80 \\
$\mathbf{5}$ classes & 14263.64 & 14462.80 & 14335.76 & $\mathrm{p}<.05$ & .81 \\
6 classes & 14219.87 & 14423.89 & 14304.60 & $\mathrm{p}=.15$ & .77 \\
\hline
\end{tabular}

\section{Discussion}

\subsection{Validity of the Spanish IGD-20 Test}

The main objective of this study was to validate a Spanish version of the IGD-20 Test and to characterize Spanish video gamers using LPA. The Spanish version of the IGD-20 Test appears to be valid at several levels and also reliable. Moreover, the results obtained from the CFA suggested that the Spanish IGD-20 Test possessed an adequate degree of factorial validity. Furthermore, criterion-validity was further evidenced by the expected associations encountered between the overall IGD-20 Test scores and main criterion variables (e.g., hours devoted to gaming during the week and participants' age). In addition, the IGD-20 Test has proven itself to be an instrument capable of identifying various subgroups within a broader sample.

\subsection{Gamers' latent profiles}

The gamers who participated in the study were from various Spanish speaking countries in Europe and Latin America and appeared to represent the average gamer in the sense that they were single, young, started playing videogames as children, and had a high degree of engagement, as demonstrated by the use of more than one videogame platform to play various game genres.

According to the LPA, $2.6 \%$ of the participants belonged to the
Table 5

Comparison of the predictors of the latent class analysis.

\begin{tabular}{|c|c|c|c|c|c|}
\hline & Casual & Regular & Low risk & High risk & Disordered \\
\hline & Mean & Mean & Mean & Mean & Mean \\
\hline Salience & $1.70 \mathrm{a}$ & $2.72 \mathrm{~b}$ & $3.26_{c}$ & $3.82 \mathrm{~d}$ & $4.54 \mathrm{e}$ \\
\hline Mood & $2.11 \mathrm{a}$ & $2.71 \mathrm{~b}$ & $3.41_{\mathrm{c}}$ & $3.39_{c}$ & $3.91_{\mathrm{c}}$ \\
\hline Tolerance & $1.41 \mathrm{a}$ & $1.99 \mathrm{~b}$ & $2.60_{c}$ & $2.89 \mathrm{~d}$ & $3.74 \mathrm{e}$ \\
\hline Withdrawal & $1.19 \mathrm{a}$ & $1.74_{\mathrm{b}}$ & $3.01 \mathrm{c}$ & $2.25 \mathrm{~d}$ & $4.20 \mathrm{e}$ \\
\hline Conflict & $1.49 \mathrm{a}$ & $2.12 \mathrm{~b}$ & $2.62 \mathrm{~b}$ & $3.30_{c}$ & $3.80_{\mathrm{d}}$ \\
\hline Relapse & $1.48 \mathrm{a}$ & $2.30_{\mathrm{b}}$ & $2.55_{\mathrm{b}}$ & $3.49 \mathrm{c}$ & $4.03 \mathrm{~d}$ \\
\hline IGD-20 Test & $30.68 a$ & $45.21 \mathrm{~b}$ & $57.95_{c}$ & $64.99_{\mathrm{d}}$ & 80.43 e \\
\hline Age & $27.33 a$ & $25.88_{b}$ & $25.53 \mathrm{bc}$ & 24.47 bc & $22.14_{c}$ \\
\hline Hours & $12.11 \mathrm{a}$ & $20.81 \mathrm{~b}$ & $24.47 \mathrm{bc}$ & $30.51 \mathrm{c}$ & $40.00_{\mathrm{d}}$ \\
\hline
\end{tabular}

Note. Values in the same row but with different subscripts are significantly differen with $\mathrm{p}<.05$ on the Wald contrast test.

group of "disordered gamers". It should also be noted that this prevalence cannot be extrapolated to the general population because probability sampling was not conducted and because the method used to identify the gold standard and cutoff point was purely statistical (i.e., LPA) rather than clinical (i.e., based on a clinical sample). Despite these caveats, the preliminary results obtained may provide a useful starting point in the gathering of information on the presence of IGD among Spanish-speaking gamers. It is difficult to compare the prevalence rate found here with data from other studies due to the diversity of the instruments used and the variety of cultural contexts and types of gamers involved. Bearing this limitation in mind, the prevalence rate of IGD found in the present study (i.e., 2.6\%) indicates a slightly lower and yet highly comparable prevalence than those found in other European countries: 3\% in Germany (Rehbein, Kleimann, \& Mossle, 2010) and Netherlands (Haagsma, Pieterse, \& Peters, 2012; VanRooij, Schoenmakers, Vermulst, van den Eijnden, \& van de Mheen, 2010) and 4.1\% in Norway (Mentzoni et al., 2011). Moreover, the prevalence rate reported here is much more conservative than those reported by Pontes et al. (2014) in the original IGD-20

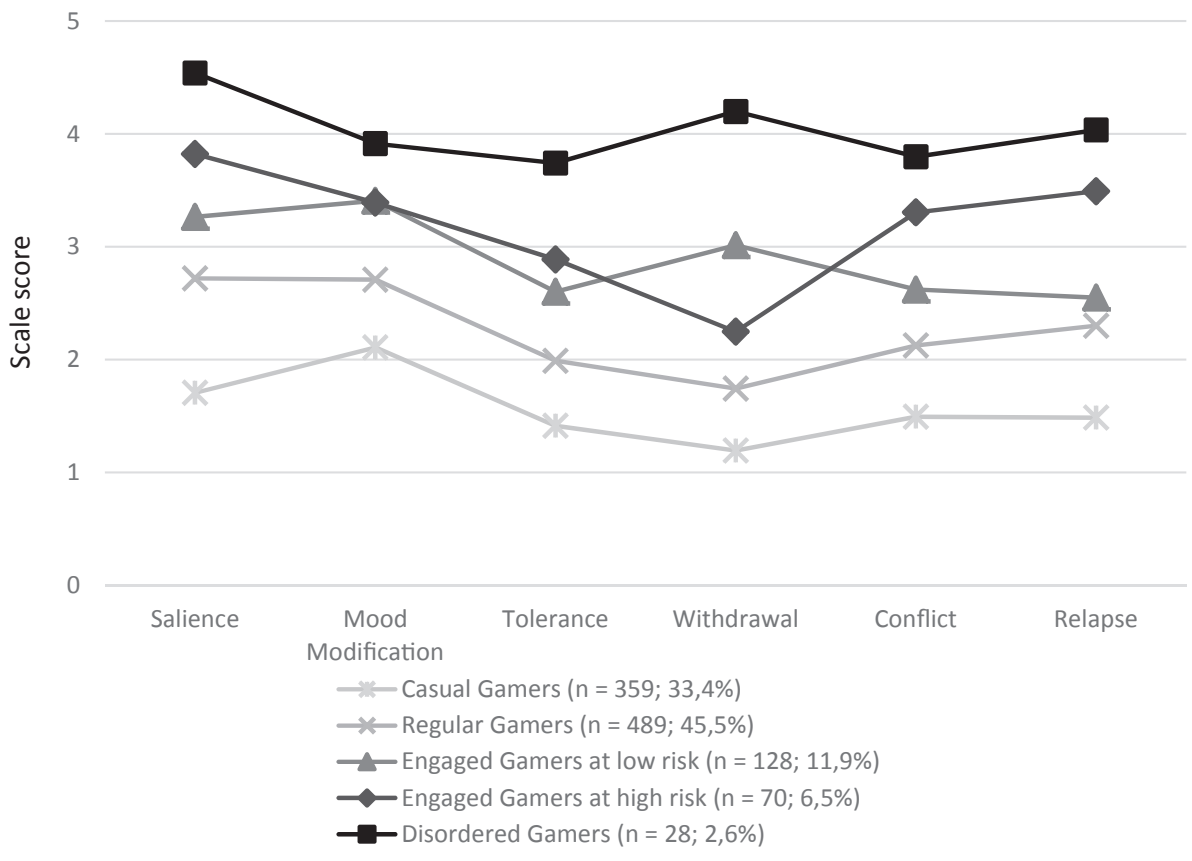

Fig. 2. Classes resulting from the latent profile analysis. 


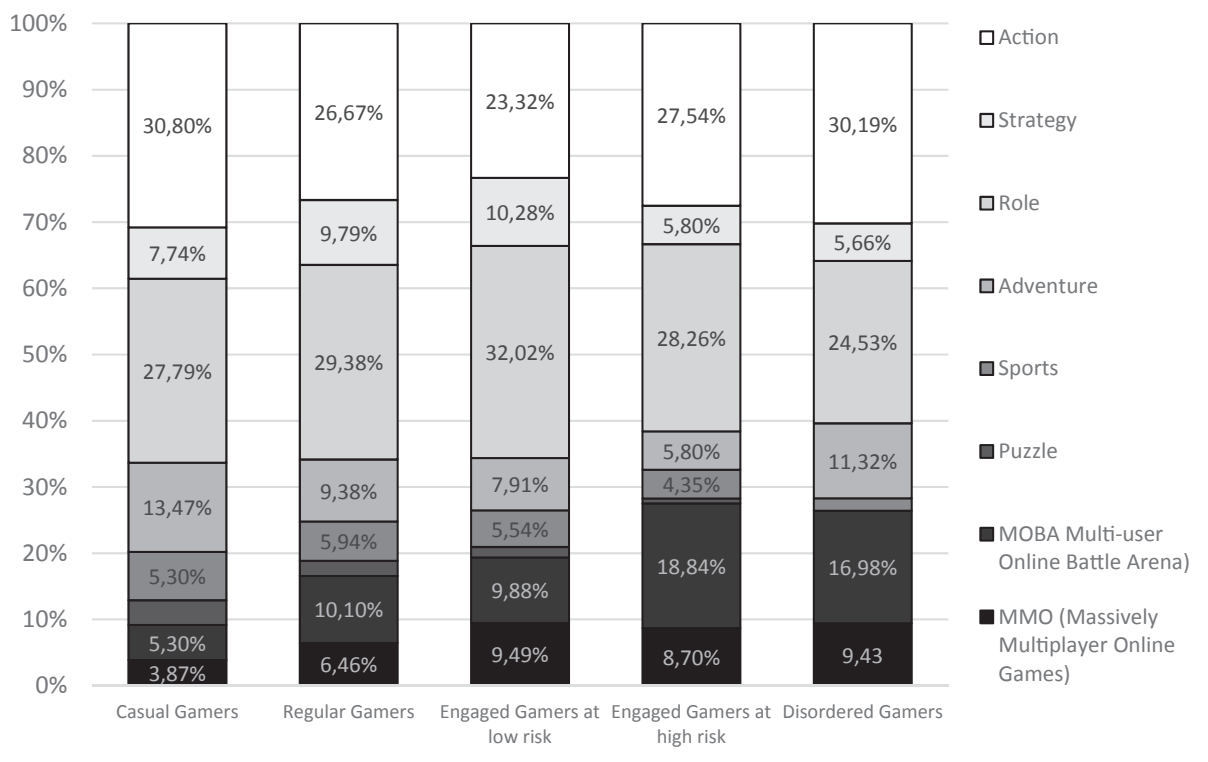

Fig. 3. Favorite genres by gamer class.

Table 6

Comparison of means for age, hours of play and IGD-20 score by game genres.

\begin{tabular}{|c|c|c|c|c|c|c|c|c|}
\hline & Action & Strategy & Role & Adventure & Sports & Puzzle & MOBA & MMO \\
\hline & Mean & Mean & Mean & Mean & Mean & Mean & Mean & Mean \\
\hline IGD-20 & $43.34 \mathrm{ab}$ & $43.36 \mathrm{ab}$ & $44.42 \mathrm{a}$ & $41.51_{b}$ & $41.51_{\mathrm{ab}}$ & $39.96 \mathrm{ab}$ & $48.75_{c}$ & $49.06_{c}$ \\
\hline Age & $26.32 \mathrm{a}$ & $25.77 \mathrm{a}$ & $26.24 \mathrm{a}$ & $26.89 \mathrm{a}$ & $26.79 \mathrm{a}$ & $28.45 \mathrm{a}$ & $23.96_{b}$ & $25.95 \mathrm{a}$ \\
\hline Hours & $18.12 \mathrm{a}$ & $17.60 \mathrm{abc}$ & $20.36_{b}$ & $14.56_{c}$ & $13.43 \mathrm{~cd}$ & $12.11_{\mathrm{d}}$ & 26.63 e & $31.75 \mathrm{e}$ \\
\hline
\end{tabular}

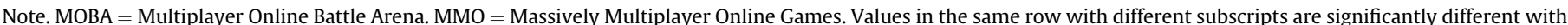
$\mathrm{p}<.05$ on the pairwise test of mean equality. The tests were adjusted for multiple comparisons using the Bonferroni correction.

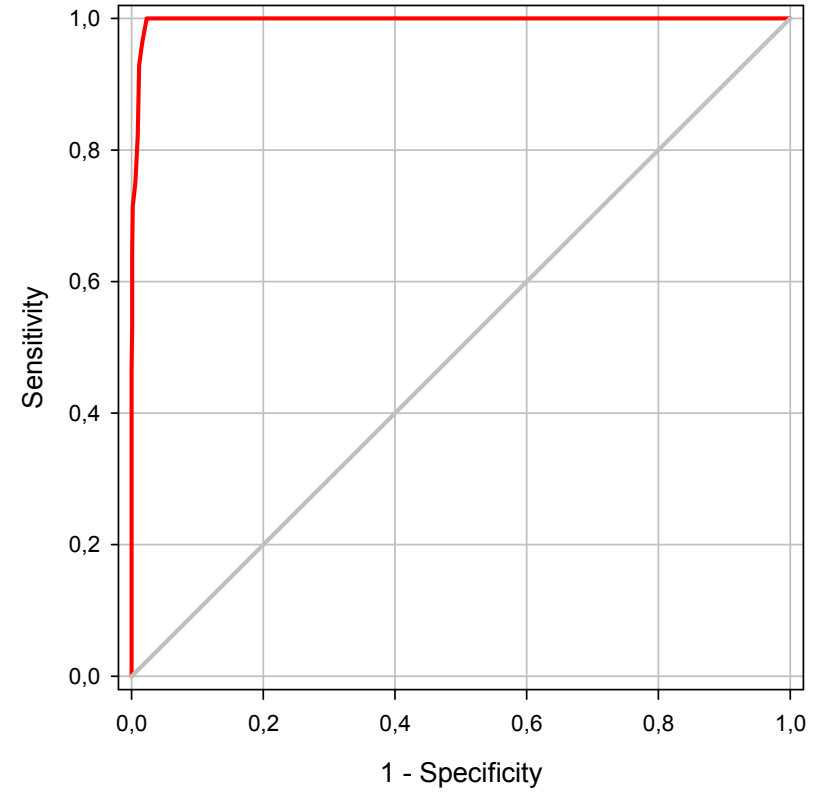

Fig. 4. The Receiver Operating Characteristic (ROC) curve of the Spanish version of the IGD-20 Test.
Test study (i.e., 5.3\%), which is likely to reflect differences in the sample and sampling techniques employed due to lack of probability sampling.

Nevertheless, the use of a common instrument to assess IGD allows for new and more reliable IGD studies to be carried out

Table 7

Cutoff points for the IGD-20 Test based on the disordered gamers' class obtained through latent profile analysis.

\begin{tabular}{rrrrrrrrrl}
\hline & TP & TN & FP & FN & Sensitivity & Specificity & PV+ & \multicolumn{1}{l}{ PV- } & ACC \\
\hline 70 & 28 & 1022 & 24 & 0 & $100.00 \%$ & $97.71 \%$ & $53.85 \%$ & $100.00 \%$ & $97.77 \%$ \\
71 & 27 & 1029 & 17 & 1 & $96.43 \%$ & $98.37 \%$ & $61.36 \%$ & $99.90 \%$ & $98.32 \%$ \\
72 & 26 & 1034 & 12 & 2 & $92.86 \%$ & $98.85 \%$ & $68.42 \%$ & $99.81 \%$ & $98.70 \%$ \\
73 & 23 & 1036 & 10 & 5 & $82.14 \%$ & $99.04 \%$ & $69.70 \%$ & $99.52 \%$ & $98.60 \%$ \\
74 & 21 & 1040 & 6 & 7 & $75.00 \%$ & $99.43 \%$ & $77.78 \%$ & $99.33 \%$ & $98.79 \%$ \\
75 & 20 & 1044 & 2 & 8 & $71.43 \%$ & $99.81 \%$ & $90.91 \%$ & $99.24 \%$ & $99.07 \%$ \\
76 & 18 & 1045 & 1 & 10 & $64.29 \%$ & $99.90 \%$ & $94.74 \%$ & $99.05 \%$ & $98.98 \%$ \\
77 & 16 & 1045 & 1 & 12 & $57.14 \%$ & $99.90 \%$ & $94.12 \%$ & $98.86 \%$ & $98.79 \%$ \\
78 & 15 & 1045 & 1 & 13 & $53.57 \%$ & $99.90 \%$ & $93.75 \%$ & $98.77 \%$ & $98.70 \%$ \\
79 & 13 & 1046 & 0 & 15 & $46.43 \%$ & $100.00 \%$ & $100.00 \%$ & $98.59 \%$ & $98.60 \%$ \\
80 & 11 & 1046 & 0 & 17 & $39.29 \%$ & $100.00 \%$ & $100.00 \%$ & $98.40 \%$ & $98.42 \%$ \\
\hline
\end{tabular}

Note. $\mathrm{TP}=$ True positives. $\mathrm{TN}=$ True negatives. $\mathrm{FP}=$ False positives. $\mathrm{FN}=$ False negatives. $\mathrm{PV}+=$ Positive predictive value. $\mathrm{PV}-=$ Negative predictive value ACC $=$ Accuracy. 
across various cultural spectrums, ultimately helping clarify to what degree the differences are explained by the varied instruments employed and to what extent they represent a real difference in gaming behavior. Another factor that may have played a role in these differences is that while Mentzoni et al. (2011), Rehbein et al. (2010) and Van Rooij et al. (2010) used probability sampling, both Pontes et al.'s sample (2014) and the sample in the present study came from gaming forums (i.e., convenience samples).

If the observed data with information on Spanish gamers are compared (Fuster et al., 2014), it can be seen that the gamers in the present study played fewer hours per week (19.46 h compared with $22.38 \mathrm{~h}$ ), but that there was a similar percentage of gamers playing over $30 \mathrm{~h}$ a week ( $21.1 \%$ compared to $21.2 \%$ ). Specific videogame genres might be more problematic, or at the very least appear to appeal more to "disordered gamers". Along these lines, a greater percentage of "disordered" or at-risk gamers was found among those who played MOBA and MMORPGs, and consequently it was observed that those who play these genres of games spent more time playing and scored significantly higher on the IGD-20 Test. These results corroborate both the prior research into MMORPGs and prior impressions on the use of MOBA games.

At the same time, the use of LPA resulted in the identification of the same subgroups that were identified in the original IGD-20 Test study. These groups help to draw a distinction between highly engaged gamers and truly "disordered gamers". Meanwhile, among engaged gamers, a distinction can be made between them. On the one hand, those at low-risk, who have high scores on salience, mood modification, tolerance and withdrawal, and on the other those at higher risk, who in addition to all the categories above also have high scores for conflict and relapse. As Pontes et al. (2014) pointed out, in addition to the recommended cutoff point ( 75 for the Spanish version of the IGD-20 Test), an analysis of the profile is recommended in order to identify those high-risk gamers whose scores are inflated for the three factors of withdrawal, conflict, and relapse.

This distinction between engaged gamers and "disordered gamers" suggests that some past studies may have overestimated the prevalence of videogame addicts (Charlton \& Danforth, 2007) and that the consequences of substance addiction and, as such, the diagnostic criteria used, need not have strict parallels to those required for videogame addiction. In addition to this distinction, it is necessary to take a more in-depth look at models not necessarily connected to addiction that can be applied to videogames, such as those arising from the theories of passion (Fuster et al., 2014; Vallerand et al., 2003), motivation (Yee, 2006) and compensatory use (Kardefelt-Winther, 2014).

In the present study, age was another variable associated with problem videogame use (i.e., participants belonging to the "disordered gamers" class were the youngest of classes). This finding corroborates that younger gamers are more likely to be identified as "disordered gamers", which could lead to the conclusion that as they move into other developmental stages in their lives, they will likely move on to healthier gaming patterns. A third associated variable was weekly hours of play, with gamers in the "disordered gamers" spending a mean average of $40 \mathrm{~h}$ per week playing videogames. This finding parallels the findings of similar recent studies (e.g., Fuster et al., 2014; Gentile et al., 2011; Grüsser, Thalemann, \& Griffiths, 2007; Pápay et al., 2013; Pontes et al., 2014).

Lastly, the ROC curve analysis resulted in a cutoff point of 75 for diagnosis using the Spanish version of the IGD-20 Test. This cutoff point is slightly higher than the one reported in the original version (which was 71), and this tendency bears further examination. This difference could be due to variations in ways of playing or cultural idiosyncrasies when it comes to identifying IGD symptoms. Consequently, culture-specific factors require further examination and investigation. Furthermore, Pontes et al. (2014) pointed out that the study of the identified clinical population is also necessary in order to verify these results.

\subsection{Study limitations and future research directions}

It must be noted that this study shares the limitations that were previously highlighted in the original research (Pontes et al., 2014). More specifically, this study used a convenience sample of Spanish-speaking gamers, which is not necessarily representative of all Spanish gamers. Moreover, data collection was acquired through self-reporting, which might be subject to possible biases (e.g., social desirability bias, recall bias, etc.). It is worth noting that much like in the original study, the use of online methodology led to a relatively high percentage of incomplete questionnaires (32.6\%). Finally, further research using the Spanish version of the IGD-20 Test could also utilize a clinical population to further explore and test concurrent, discriminant, and predictive criterion-related validity. The new validated test could also be used to test for correlates of pathological game use (e.g., self-control, delay discounting, personality traits, etc.), and specific types of game play (e.g., game mechanics, game genres, avatar customization, etc.).

\subsection{Conclusions}

One of the strengths of the IGD-20 Test is that it is an instrument designed on the basis of the theoretical framework of IGD as in the DSM-5, and another strength is that both online and offline gamers took part in its validation. However, as Porter, Starcevic, Berle, and Fenech (2010) point out, it is questionable whether the distinction made between online and offline gaming is necessary in light of the results showing that the majority of gamers use more than one platform to play various genres of videogames. The instrument's versatility also helps guarantee its usefulness and practicality in assessing all kinds of gamers and in determining the prevalence of problematic videogame use in large-scale surveys. It could also be used as a preliminary diagnostic tool by clinicians along with more rigorous in-depth interviewing surrounding the use and function of gaming amongst problematic users. However, it seems undeniable that specific kinds of videogame design may attract or encourage risky behavior, and that these differences should be considered in any research.

Taken as a whole, the present study validates the Spanish version of the IGD-20 Test for use in research into IGD, indicates that specific videogame genres (e.g., MMORPGs and MOBA) might have a greater addictive potential, and identifies younger gamers and those who spend the most time on this hobby as the most vulnerable gamers.

\section{Appendix A. Spanish version of the internet gaming disorder- 20 Test (IGD-20 Test)}

Instrucciones: Las siguientes afirmaciones refieren a tu actividad 
con videojuegos durante el último año (es decir, los últimos 12 meses). Por actividad con videojuegos nos referimos cualquier conducta de juego con videojuegos llevada a cabo mediante computadora (sobremesa o portátil), consola (sobremesa o portátil) y cualquier otro dispositivo (por ejemplo, tableta), de forma online u offline.

\begin{tabular}{|c|c|}
\hline \multicolumn{2}{|l|}{ IGD-20 Test } \\
\hline 1. & A menudo pierdo horas de sueño debido a largas sesiones de juego. \\
\hline $2 \mathrm{R}^{*}$. & Nunca juego a videojuegos para sentirme mejor. \\
\hline 3. & Durante el último año he aumentado significativamente la cantidad de horas de juego a videojuegos. \\
\hline 4. & Me siento más irritable cuando no estoy jugando. \\
\hline 5. & He perdido interés en otras aficiones debido a jugar. \\
\hline 6. & Me gustaría reducir mi tiempo de juego pero me resulta difícil. \\
\hline 7. & Suelo pensar en mi próxima sesión de juego cuando no estoy jugando. \\
\hline 8. & Juego a videojuegos porque me ayuda a lidiar con los sentimientos desagradables que pueda tener. \\
\hline 9. & Necesito pasar cada vez más tiempo jugando a videojuegos. \\
\hline 10. & Me siento triste si no puedo jugar a videojuegos. \\
\hline 11. & He mentido a mis familiares debido a la cantidad de tiempo que dedico a videojuegos. \\
\hline 12. & No creo que pudiera dejar de jugar. \\
\hline 13. & Creo que jugar se ha convertido en la actividad que más tiempo consume de mi vida. \\
\hline 14. & Juego a videojuegos para olvidar cosas que me preocupan. \\
\hline 15. & A menudo pienso que un día entero no es suficiente para hacer todo lo necesito hacer en el juego. \\
\hline 16. & Tiendo a ponerme nervioso si no puedo jugar por alguna razón. \\
\hline 17. & Creo que jugar ha puesto en peligro la relación con mi pareja. \\
\hline 18. & A menudo me propongo jugar menos pero acabo por no lograrlo. \\
\hline $19 R^{*}$. & Sé que mis actividades cotidianas (trabajo, educación, tareas domésticas, etc.) no se han visto negativamente afectadas por jugar. \\
\hline 20. & reo que jugar está afectando negativamente áreas importantes de mi vida. \\
\hline
\end{tabular}

Dimensiones

Prominencia: $1,7,13$

Modificación del estado de ánimo: 2R, 8, 14

Tolerancia: $3,9,15$

Síntomas de abstinencia: 4, 10, 16

Conflicto: 5, 11, 17, 19R, 20

Recaída: 6, 12, 18

* Ítems con puntaje invertido.

*** Los ítems se responden en una escala Likert de 5 puntos: 1 “Totalmente en desacuerdo", 2 “En desacuerdo", 3 "Ni de acuerdo ni en desacuerdo", 4 "De acuerdo" y 5 "Totalmente de acuerdo".

*** Punto de corte sugerido: 75 puntos.

\section{References}

American Psychiatric Association. (2013). Diagnostic and statistical manual of mental disorders (5th ed.) Washington: Author.

Andreassen, C. S., Griffiths, M. D., Hetland, J., \& Pallesen, S. (2012a). Development of a work addiction scale. Scandinavian Journal of Psychology, 53(3), 265-272. http://dx.doi.org/10.1111/j.1467-9450.2012.00947.x.

Andreassen, C. S., Griffiths, M. D., Pallesen, S., Bilder, R. M., Torsheim, T., \& Aboujaoude, E. N. (2015). The Bergen Shopping Addiction Scale: Reliability and validity of a brief screening test. Frontiers in Psychology, 6, 1374. http:// dx.doi.org/10.3389/fpsyg.2015.01374.

Andreassen, C. S., Torsheim, T., Brunborg, G. S., \& Pallesen, S. (2012b). Development of a Facebook addiction scale. Psychological Reports, 110(2), 1-17. http:/ dx.doi.org/10.2466/02.09.18.PR0.110.2.501-517.

Carbonell, X., Guardiola, E., Beranuy, M., \& Bellés, A. (2009). A bibliometric analysis of the scientific literature on Internet, video games, and cell phone addiction. Journal of The Medical Library Association, 97(2), 102-107. http://dx.doi.org 10.3163/1536-5050.97.2.006.

Chamarro, A., Carbonell, X., Manresa, J. M., Munoz- Miralles, R., Ortega-Gonzalez, R. Lopez-Morrón, M. R., ... Toran, P., et al. (2014). El Cuestionario de Experiencias Relacionadas con los Videojuegos (CERV): un instrumento para detectar el uso problemático de videojuegos en adolescentes españoles. Addicciones, 26(4), 303-311.

Charlton, J. P., \& Danforth, I. D. W. (2007). Distinguishing addiction and high engagement in the context of online game playing. Computers in Human Behavior, 23, 1531-1548. http://dx.doi.org/10.1016/j.chb.2005.07.002.

Chóliz, M., \& Marco, C. (2011). Pattern of use and dependence on video games in infancy and adolescence. Anales de Psicología, 27(2), 418-426.

Fuster, H., Chamarro, A., Carbonell, X., \& Vallerand, R. J. (2014). Relationship between passion and motivation for gaming in players of Massively Multiplaye Online Role-Playing Games. Cyberpsychology, Behavior and Social Networking 17(5), 292-297. http://dx.doi.org/10.1089/cyber.2013.0349.

Fuster, H., Oberst, U., Griffiths, M. D., Carbonell, X., Chamarro, A., \& Talarn, A. (2012) Psychological motivation in online role-playing games: a study of Spanish
World of Warcraft players. Anales de Psicologia, 28(1), 274-280.

Gentile, D. A., Choo, H., Liau, A., Sim, T., Li, D., Fung, D., et al. (2011). Pathological video game use among youths: a two-year longitudinal study. Pediatrics, 127(2), e319-e329. http://dx.doi.org/10.1542/peds.2010-1353.

Griffiths, M. D. (1995). Technological addictions. Clinical Psychology Forum, 76, 14-19.

Griffiths, M. D. (2005). A “components” model of addiction within a biopsychosocial framework. Journal of Substance Use, 10, 191-197. http://dx.doi.org/10.1080/ 14659890500114359.

Griffiths, M. D. (2010). The use of online methodologies in data collection for gambling and gaming addictions. International Journal of Mental Health and Addiction, 8, 8-20. http://dx.doi.org/10.1007/s11469-009-9209-1.

Griffiths, M. D. (2012). The use of online methodologies in studying paraphilias - a review. Journal of Behavioral Addictions, 1(4), 143-150. http://dx.doi.org/ 10.1007/s11469-009-9209-1.

Griffiths, M. D., King, D. L., \& Demetrovics, Z. (2014). DSM-5 Internet gaming disorder needs a unified approach to assessment. Neuropsychiatry, 4, 1-4. http:// dx.doi.org/10.2217/npy.13.82.

Griffiths, M. D., Király, O., Pontes, H. M., \& Demetrovics, Z. (2015). An overview of problematic gaming. In V. Starcevic, \& E. Aboujaoude (Eds.), Mental Health in the Digital Age: Grave Dangers, Great Promise (pp. 27-45). Oxford: Oxford University Press.

Griffiths, M. D., Kuss, D. J., \& King, D. (2012). Video Game addiction: past, present and future. Current Psychiatry Reviews, 8(4), 308-318. http://dx.doi.org/10.2174/ 157340012803520414

Grüsser, S., Thalemann, R., \& Griffiths, M. D. (2007). Excessive computer game playing: evidence for addiction and aggression? CyberPsychology and Behavior, 10(2), 290-292. http://dx.doi.org/10.1089/cpb.2006.9956.

Haagsma, M. C., Pieterse, M. E., \& Peters, O. (2012). The prevalence of problematic video gamers in The Netherlands. Cyberpsychology, Behavior, and Social Networking, 15(3), 162-168. http://dx.doi.org/10.1089/cyber.2011.0248.

Hill, A. L., Degnan, K. A., Calkins, S. D., \& Keane, S. P. (2006). Profiles of externalizing behavior problems for boys and girls across preschool: the roles of emotion regulation and inattention. Developmental Psychology, 42(5), 913.

Hu, L. T., \& Bentler, P. M. (1999). Cutoff criteria for fit indexes in covariance structure 
analysis: Conventional criteria versus new alternatives. Structural Equation Modelling, 6(1), 1-55.

Kardefelt-Winther, D. (2014). Problematizing excessive online gaming and its psychological predictors. Computers in Human Behavior, 31, 118-122. http:// dx.doi.org/10.1016/j.chb.2013.10.017.

Kuss, D. J., Shorter, G. W., van Rooij, A. J., Griffiths, M. D., \& Schoenmakers, T. M. (2014). Assessing Internet addiction using the parsimonious Internet addiction components model - a preliminary study. International Journal of Mental Health and Addiction, 12, 351-366.

Labrador, F. J., Villadangos, S. M., Crespo, M., \& Becoña, E. (2013). Desarrollo y validación de un cuestionario del problematico de nuevas tecnologias. Anales de Psicología, 29(3), 836-847.

Lanza, S. T., Flaherty, B. P., \& Collins, L. M. (2003). Latent class and latent transition analysis. In J. A. Schinka, \& W. A. Velicer (Eds.), Handbook of psychology: Research methods in psychology (pp. 663-685). New York, NY: Wiley.

Lemmens, J. S., Valkenburg, P. M., \& Peter, J. (2009). Development and validation of a game addiction scale for adolescents. Media Psychology, 12(1), 77-95.

Little, R. J., \& Rubin, D. B. (1987). Statistical analysis with missing data. New York, NY: Wiley.

Lopez-Fernandez, O. (2015). How has internet addiction research evolved since the advent of Internet Gaming Disorder? an overview of cyberaddictions from a psychological perspective. Current Addiction Reports, 2, 263-271. http:// dx.doi.org/10.1007/s40429-015-0067-6.

Lopez-Fernandez, O., Freixa-Blanxart, M., \& Honrubia-Serrano, M. L. (2013). The problematic internet entertainment use scale for adolescents: prevalence of problem internet use in Spanish high school students. Cyberpsychology, Behavior and Social Networking, 16(2), 108-118. http://dx.doi.org/10.1089/ cyber.2012.0250.

Mentzoni, R. A., Brunborg, G. S., Molde, H., Myrseth, H., Skouverøe, K. J. M., Hetland, J., et al. (2011). Problematic video game use: estimated prevalence and associations with mental and physical health. Cyberpsychology, Behavior and Social Networking, 14(10), 591-596. http://dx.doi.org/10.1089/cyber.2010.0260.

Muthén, L. K., \& Muthén, B. O. (2011). Mplus user's guide (6th ed.). Los Angeles: CA: Muthén \& Muthén.

Pápay, O., Urbán, R., Griffiths, M. D., Nagygyörgy, K., Farkas, J., Kökönyei, G., ... Demetrovics, Z., et al. (2013). Psychometric properties of the problematic online gaming questionnaire short-form and prevalence of problematic online gaming in a national sample of adolescents. Cyberpsychology, Behavior and Social Networking, 16(5), 340-348. http://dx.doi.org/10.1089/cyber.2012.0484.

Pedrero, E. J., Rodríguez, M. T., Gallardo, F., Fernández, M., Pérez, M., \& Chicharro, J. (2007). Validación de un instrumento para la detección de trastornos de control de impulsos y adicciones: el MULTICAGE CAD-4. Trastornos Adictivos, 9(4), 269-278.
Petry, N. M., \& O'Brien, C. P. (2013). Internet gaming disorder and the DSM-5 Addiction, 108(7), 1186-1187. http://dx.doi.org/10.1111/add.12162.

Petry, N. M., Rehbein, F., Gentile, D. A., Lemmens, J. S., Rumpf, H., Mößle, T., et al. (2014). An international consensus for assessing internet gaming disorder using the new DSM-5 approach. Addiction, 109, 1399-1406. http://dx.doi.org/10.1111 add.12457.

Petry, N. M., Rehbein, F., Ko, C.-H., \& O'Brien, C. P. (2015). Internet gaming disorder in the DSM-5. Current Psychiatry Reports, 17(9), 1-9. http://dx.doi.org/10.1007/ s11920-015-0610-0.

Pontes, H. M., \& Griffiths, M. D. (2014). Assessment of internet gaming disorder in clinical research: past and present perspectives. Clinical Research and Regulatory Affairs, 31(2-4), 35-48.

Pontes, H. M., Király, O., Demetrovics, Z., \& Griffiths, M. D. (2014). The conceptualisation and measurement of DSM-5 Internet Gaming Disorder: the development of the IGD-20 Test. PloS ONE, 9(10), e110137. http://dx.doi.org/ 10.1371/journal.pone.0110137.

Porter, G., Starcevic, V., Berle, D., \& Fenech, P. (2010). Recognizing problem video game use. Australian and New Zealand Journal of Psychiatry, 44(2), 120-128. http://dx.doi.org/10.3109/00048670903279812.

Rehbein, F., Kleimann, M., \& Mossle, T. (2010). Prevalence and risk factors of video game dependency in adolescence: results of a German nationwide survey. Cyberpsychology, Behavior and Social Networking, 13(3), 269-277. http:/| dx.doi.org/10.1089/cyber.2009.0227.

Sperber, A. D. (2004). Translation and validation of study instruments for crosscultural research. Gastroenterology. 126, S124-S128. http://dx.doi.org/ 10.1053/j.gastro.2003.10.016.

Tabachnick, B. G., \& Fidell, L. S. (2007). Multivariate statistics (5th ed.). Boston: Pearson.

Tejeiro, R., \& Bersabé, R. M. (2002). Measuring problem video game playing in adolescents. Addiction, 97, 1601-1606.

Terry, A., Szabo, A., \& Griffiths, M. D. (2004). The Exercise Addiction Inventory: a new brief screening tool. Addiction Research and Theory, 12, 489-499.

Vallerand, R. J., Blanchard, C. C., Mageau, G. A., Koestner, R., Ratelle, C., Leonard, M., et al. (2003). Les passions de l'âme: on obsessive and harmonious passion. Journal of Personality and Social Psychology, 85(4), 756-767. http://dx.doi.org/ 10.1037/0022-3514.85.4.756.

Van Rooij, A. J., Schoenmakers, T. M., Vermulst, A. A., van den Eijnden, R. J. J., \& van de Mheen, D. (2010). Online video game addiction: identification of addicted adolescent gamers. Addiction, 106, 205-222. http://dx.doi.org/10.1111/j.13600443.2010.03104.x.

Yee, N. (2006). Motivations for play in online games. CyberPsychology and Behavior 9(6), 772-775. http://dx.doi.org/10.1089/cpb.2006.9.772. 